\title{
CULTURA DE MASSAS E PAPÉIS FEMININOS NA CONSTRUÇÃO DE ÍCONES DA MODERNIDADE, NA PAULICÉIA DOS ANOS 20
}

\author{
Maria Inez Machado Borges Pinto \\ Profa. Dra. Depto. de História/FFLCH-USP
}

RESUMO: Este artigo pretende analisar criticamente o discurso sobre o consumo, bem como sua mensagem de que a felicidade das mulheres depende da aquisição de objetos desejados, através do consumo de produtos de massa, veiculado nos anos 20 pela publicidade, pela fotografia e pelo cinema. O cinema hollywoodiano neste período era estruturado em parte, sobre a apresentação da mulher como objeto glamouroso, disputado e consumido, e em parte sobre a criação do mise-en-scène cujos fetiches são objetos consumidos e o estilo de vida consumista como corolário da modernidade.

PALAVRAS CHAVE: Cultura de Massas, Cinema, Representações Femininas, Urbanização, Modernidade.

ABSTRACT: This article analyses the discourse of consume as well as its message that the women's happiness depends on the consume of mass products that were vehicled in the twenties by the publicity, photography and the movies. The Hollywood movies in that time showed the women as glamorous objects, disputed and consumed, and the consumist way of llife as the corollary of modernity.

KEYWORDS: Mass Culture, Movies, Female Representations, Urbanization, Modernity.

O século XX é marcado por um intenso fluxo de mudanças de todas as ordens, econômicas, políticas e sociais, atingindo os modos de percepção e interferindo diretamente nos processos de interpretação e reelaboração dos signos culturais que compõem o cotidiano dos indivíduos, inserindo uma nova noção de tempo e de espaço, provocando novas reações que respondem a novas sensações, incitando novos desejos incontidos de consumo bem como novas maneiras de sociabilidade e sociabilização. 
Contribuiu enormemente para isso a Segunda Revolução Industrial ou a Revolução Científico-Tecnológica, ocorrida em meados de 1870 e que foi responsável pelo enorme avanço tecnológico até então nunca alcançado, apresentando a possibilidade de novos recursos técnicos que pelas suas características mesmo, desorientam, intimidam, perturbam, confundem, distorcem e alucinam, pois as escalas, potenciais e velocidades envolvidos nos novos equipamentos e instalações excedem em absoluto as proporções e as limitadas possibilidades de percepção, força e deslocamento do corpo humano:

(...) surgirão, apenas para se ter uma breve idéia, os veículos automotores, os transatlânticos, os aviões, o telégrafo, o telefone, a iluminação elétrica e a ampla gama de utensílios eletrodomésticos, a fotografia, o cinema, a radiodifusão, a televisão, os arranha-céus e seus elevadores, as escadas rolantes e os sistemas metroviários, os parques de diversões elétricas, as rodas gigantes, as montanha-russas, a seringa hipodérmica, a anestesia, a penicilina, o estetoscópio, o medidor de pressão arterial, os processos de pasteurização e esterilização, os adubos artificiais, os vasos sanitários com descarga automática e o papel higiênico, a escova de dentes e o dentrifício, o sabão em pó, os refrigerantes gasosos, o fogão a gás, o aquecedor elétrico, a Coca-Cola, a aspirina, o Sonrisal (...) (SEVCENKO, 1998, p.9).

Concomitantemente as mudanças de natureza tecnológicas, políticas e sociais, a Revolução Científico-Tecnológica impulsiona a consolidação da unidade global do mercado capitalista, fundando uma dinâmica expansionista, gerando gigantescos complexos industriais, exigindo em contrapartida ao aumento de produção a abertura de novos mercados consumidores capazes de devorar tudo o que tivesse preço. Foi essa ampliação na escala das demandas e das exportações que gerou o fenômeno conhecido como neocolonialismo ou imperialismo e que mais do que simplesmente incorporar política e economicamente as nações "atrasadas", buscava transformar o modo de vida dessas sociedades tradicionais, corrompendo-lhes os hábitos e condenando-lhes seus comportamentos para então, incutir-lhes hábitos e práticas de produção e consumo, bem como atitudes e pensamentos modernos.

No caso do Brasil, o aparecimento de um novo regime político, ancorado em bases econômicas muito específicas viria deixar para trás o Império e suas mazelas e anunciar a ascensão de uma nova base social muito diversa daquela, ancorada política e economicamente nas riquezas geradas pela expansão da cultura cafeeira no Sudeste do país. Assim, com a inauguração da República, a idéia das novas elites era a de promover a industrialização imediata e a modernização do país "a todo custo", abrindo para isso a economia aos capitais estrangeiros, especialmente ingleses e americanos, além de promover a mais escandalosa fraude especulativa de todos os tempos no mercado de ações, o "Encilhamento". O efeito direto desse processo foi um desastre econômico que arruinou os capitalistas mais ricos, ou seja, aqueles que constituíram a elite econômica da monarquia, facilitando assim "a ascensão de uma nova camada de arrivistas, enriquecidos no jogo especulativo e nas negociatas dos primeiros anos do novo regime e que paradoxalmente se transformaria, junto aos cafeicultores do Sudeste, nas principais bases sociais e econômicas de sustentação da elite científica e tecnocrática inspirada no rígido racionalismo positivista"(SEVCENKO, 1998, p.15).

$\mathrm{Na}$ mesma época em que esses "homens novos" ascendem, dá-se a Abolição (1888), a imigração estrangeira avulta e se consolidam as práticas do trabalho assalariado e a constituição de um mercado interno dinâmico, gerando assim um amplo processo de desestabilização da sociedade e cultura tradicionais. No afã modernizador, as novas elites se empenhavam em reduzir a complexa realidade social brasileira em conformidade com padrões abstratos de gestão social copiados de modelos europeus ou norte-americanos, modelos esses que pregavam a civilidade, o urbanismo científico e o apagamento do passado histórico do país, singularizado pelas mazelas herdadas do colonialismo e da escravidão. 
Mais especificamente, São Paulo na década de 20 passava por transformações de todas as naturezas: econômicas, sociais, administrativas e principalmente culturais. Seu semblante não era totalmente conhecido pois ainda se formava, apoiado, por um lado na influência do modelo civilizador e modernizador da Belle Époque européia - particularmente a francesa e de outro numa sólida herança cultural, advinda das nossas raízes coloniais.

A despeito do processo de 'regeneração', caracterizado pela reforma urbana do Rio de Janeiro, pela modernização do porto, pela campanha saneadora da vacina obrigatória e pela Grande Exposição Nacional; frente a condenação dos hábitos e costumes ligados pela memória à sociedade tradicional; a negação de todo e qualquer elemento de cultura popular que pudesse macular a imagem civilizada da sociedade dominante; uma política rigorosa de exclusão dos grupos populares da área central da cidade e um cosmopolitismo profundamente identificado com a vida parisiense; o que se via em São Paulo na mesma época divergia completamente desse quadro:

“(...) São Paulo era uma correria sôfrega para escavar raízes tradicionais e restabelecer uma 'memória' de tinturas coloniais; um empenho pelo resgate e identificação com uma cultura popular, mormente de recorte 'sertanejo'; uma busca de áreas periféricas ao centro, à procura dos espaços livres para corridas e esportes, do pública para as façanhas e da animação popular para o Carnaval e as novas celebrações; e um curioso modernismo parisiense, que ensinava a desprezar a velha Europa moribunda e a amar a pujança da América” (SEVCENKO, 1992, p.255).

A cidade de São Paulo era caracterizada por um cosmopolitismo contraditório marcado pelos tensionamentos advindos da coexistência de diferentes temporalidades, onde conviviam lado a lado nas produções e reproduções da vida cotidiana, o arcaico e o moderno, o novo e o velho, configurando diversos ritmos sociais que imprimiam à cidade uma feição heterogênea. Nos anos 20, São Paulo "encarnava a imagem de uma metrópole inacabada, moderna e provinciana, de um país periférico, das enchentes e da pobreza"(LOTITO, 1997), equilibrando-se entre um modelo europeu de urbanidade e a convivência inventiva e improvisada entre inúmeras etnias e entre os novos grupos sociais que se formavam.

(...) Afinal, São Paulo não era uma cidade nem de negros, nem de brancos e nem de mestiços; nem de estrangeiros e nem de brasileiros; nem americana, nem européia, nem nativa; nem era industrial, apesar do volume crescente das fábricas, nem entreposto agrícola, apesar da importância crucial do café; não era tropical, nem subtropical; não era ainda moderna, mas já não tinha mais passado. Essa cidade que brotou súbita e inexplicavelmente, como um colossal cogumelo depois da chuva, era um enigma para seus próprios habitantes, perplexos, tentando entendê-lo como podiam, enquanto lutavam para não serem devorados (SEVCENKO, 1992, p.31).

Em 1920, o valor da produção paulista passava da metade da produção geral da União. São Paulo era a "locomotiva carregando atrás de si vinte vagões vazios", como se dizia então. O ritmo das transformações se acelera. Há uma expansão horizontal na cidade que deslinda novos bairros enquanto os antigos se remodelam, no centro apontam os primeiros prédios; São Paulo pela primeira vez conhece, nos anos 20, um rush imobiliário, marcado pela especulação de terrenos. São Paulo civiliza-se. Freqüenta escolas, clubes, cafés-concerto, teatros e cinemas. Movimentase ao ritmo dos maxixes e dos sambas, dos ragimes, one-steps e tangos. Os salões burgueses se aristocratizam, recobrem-se de savonneries e móveis franceses; além de professores de música. É todo refinamento de uma cultura urbana e burguesa que se estrutura e irradia para as classes médias (GALVÃO, 1975).

As camadas médias iam consolidando-se, agregando trabalhadores dos setores ferroviário e dos serviços urbanos, como empresas de energia, transportes, água, telefone, comércio importador e construção civil, que cresciam junto com a cidade. Engrossavam as camadas médias, os pequenos proprietários rurais 
empobrecidos que, na cidade, passaram a ocupar os cargos mais elevados do aparelho burocrático ou tornaram-se profissionais liberais. Os brasileiros de origem mais pobre e os imigrantes ocupavam os cargos inferiores no funcionalismo público, nos serviços de escritório, nos setores bancário, industrial e comercial (LOTITO, 1997, p.7).

Analisando a estrutura do mercado de trabalho da metrópole paulistana nos fins do século XIX e nas primeiras décadas do século XX, observa-se que a formação e consolidação deste mercado de trabalho interno livre se dá com a predominância acentuada e a proliferação das pequenas ocupações autônomas e do trabalho informal, setores incluídos na chamada economia invisível, oculta, subterrânea, submersa, informal, paralela, não oficial; são tantos os seus nomes quanto as dificuldades para dimensioná-la. Era caracterizada principalmente por pequenas ocupações independentes e trabalhos ocasionais, que vigoravam tanto nos tempos de euforia e expansão como de estagnação da economia. Os entraves da economia à acomodação do homem pobre no processo produtivo, o rápido crescimento demográfico de uma população pobre, desempregada, trazida pela corrente imigratória, e a frequiência das flutuações cíclicas de suas atividades, geraram o crescimento vegetativo de uma massa desenraizada, vivendo numa situação ambígua de participação-exclusão, cujas possibilidades de se integrar nas profissões lucrativas estáveis eram reduzidíssimas, estando condenada ao semi-emprego crônico.

Entre as pequenas profissões que dominavam a paisagem agitada e movimentada da Paulicéia, temos que ressaltar a grande importância do pequeno artesanato autônomo. Uma enorme "profusão de minúsculas oficinas caseiras, pequenas empresas familiares, em geral, pouco lucrativas, localizadas em prédios malcuidados, pobres, no fundo do quintal ou de algum cômodo da casa de seu proprietário, compunham a arquitetura da cidade, revelando o peso significati- vo do artesanato autônomo para a sobrevivência cotidiana dos trabalhadores pobres que não conseguiam obter um trabalho estável assalariado" (PINTO, 1994, p.114).

Por outro lado, nas indústrias que se formavam, principalmente as têxteis, a introdução da maquinaria tende a reduzir o valor da força de trabalho e a lançar ao mercado crianças e mulheres em maior proporção. Como observa Boris Fausto, "as mulheres, em 1919, são majoritárias no ramo têxtil no Estado de São Paulo e representam uma parcela significativa no Distrito Federal, por sua vez constituem maioria no ramo de vestuário e toucador na Capital da República. A introdução da força de trabalho feminina e infantil resulta em novas fontes de atritos, pois para os homens, o trabalho feminino se transforma em um temível concorrente:

Em 1917, no curso de uma assembléia da União dos Operários em Fábricas de Tecidos do Rio de Janeiro, convocada para discutir a situação existente em uma fábrica onde os tecelões estavam sendo gradativamente substituídos por mulheres, um operário insurge-se contra esse processo em nome da divisão tradicional dos papéis sociais: 'nós não devemos ensinar (o trabalho) a essas mulheres que amanhã nos virão a substituir, mas devemos fazer-lhes compreender que o seu lugar é em casa, a tratar e educar seus filhos..., oxalá que elas saibam compreender seu papel de educadoras daqueles que amanhã serão os nossos substitutos na luta do pão e na conquista do bem estar da humanidade, pois, assim, demonstrarão à sociedade serem as verdadeiras rainhas do lar; o papel de uma mãe não consiste em abandonar seus filhos em casa e ir para a fábrica trabalhar, pois tal abandono origina muitas vezes conseqüências lamentáveis, quando melhor seria que somente o homem procurasse produzir de forma e prover as necessidades do lar" (FAUSTO, 1976, p.110-116).

O perfil das mulheres brasileiras nas três primeiras décadas deste século foi traçado por um vigoroso discurso ideológico, que reunia conservadores e diferentes matizes de reformistas, acabando por desumanizálas como sujeitos históricos, ao mesmo tempo que cristalizava determinados tipos de comportamento con- 
vertendo-os em rígidos papéis sociais. "A mulher que é, em tudo, o contrário do homem", foi o bordão que sintetizou o pensamento de uma época intranquiila e por isso ágil na construção e difusão das representações do comportamento feminino ideal, que limitaram seu horizonte ao "recôndito do lar" e reduziram ao máximo suas atividades e aspirações, até encaixá-la no papel de "rainha do lar", sustentada pelo tripé mãe-esposa-dona de casa (MALUF e MOTT, 1998, p.373). A imagem da mãe-esposa-dona de casa como a principal função da mulher correspondia àquilo que era pregado pela Igreja, ensinado pelos médicos em seus discursos higienistas e os juristas, legitimado pelo Estado e divulgado pela imprensa.

Segundo estudo de Marina Maluf e Maria Lúcia Mott sobre a reprodução do cotidiano e a coesão da família, atribuições que a ética dominante faz recair pesadamente sobre as mulheres, ambos os sexos elegeram como os legítimos responsáveis pela suposta corrosão da ordem social e a quebra de costumes, as inovações nas rotinas das mulheres e, principalmente, as modificações nas relações entre homens e mulheres; conjugando-se esforços para disciplinar toda e qualquer iniciativa que pudesse ser interpretada como ameaçadora à ordem familiar: “(...) Hoje em dia, preocupada com mil frivolidades mundanas, passeios, chás, tangos e visitas, a mulher deserta do lar. É como se a um templo se evadisse um ídolo. É como se a um frasco se evolasse um perfume.(...) a família se dissolve e perde a urdidura firme e ancestral dos seus liames. 'Rumo à cozinha! Eis o lema do momento" (MALUF e MOTT, 1998, p. 372).

Ainda segundo o mesmo estudo, o Código Civil de 1916 fixou socialmente o papel da mulher, suas relações com seus cônjuges, seus deveres e obrigações bem como seus corretivos, visando sempre assegurar a ordem familiar. Aqui, a mulher era inibida de trabalhar, a não ser com uma autorização prévia do seu esposo e com fins de ajuda no sustento do lar, pois a cada representante da sociedade matrimonial cabia um atributo essencial: se ao marido cabia prover a manutenção da família, à mulher restava a identidade social como esposa e mãe; a ele a identidade pública, a ela a doméstica. A contrapartida do marido provedor era a mulher responsável pela honra familiar, pois diante de tantos perigos e incertezas que assolavam a sociedade moderna e urbana, o lar e a família foram convertidos em ancoradouros da moral sagrada.

Dentro desse discurso moralizador publicizado pela imprensa e ditado pelo próprio Código Civil, vemos emoldurar-se as condutas femininas através de certas 'revistas para moças` da época, que nos deixam entrever nas entrelinhas de seus discursos a elaboração de novas estratégias de ação com o objetivo de preservar o tradicional modelo matrimonial, pois que a urbanização punha em convívio tradições e costumes tão díspares e mesclados que era necessário a imposição de uma missão modeladora do pensamento e do comportamento do homem moderno.

Porém, apesar desse desejo fomentado pelos intelectuais e profissionais das camadas dominantes de espelhar o novo cidadão brasileiro em imagens de uma burguesia urbana, cosmopolita e civilizada, o que de fato ocorreu foi que esse padrão de comportamento burguês bem como a modernidade e o consumo foram absorvidos de forma desigual pelas diferentes regiões e cidades e pelas diferentes camadas da população. Grande parte do país permaneceu fiel à agricultura e nem a industrialização, embora tenha deslocado progressivamente a produção para fora do domicílio, não destruiu de uma só vez as formas tradicionais de produção e sobrevivência. Além disso, a maioria das mulheres pobres "vivia relações conjugais consensuais, sem uma presença masculina efetiva no lar, ou conviviam com companheiros que não tinham trabalho nem efetivo nem regular", assim, além dos serviços domésticos realizados a duras penas, cuidavam dos filhos do casal e proviam a sobrevivência da família através de seus trabalhos (DIAS, 1984). 
De modo geral, os salários reduzidos e intermitentes do homem obrigavam todo membro da família pobre a procurar algum meio de ganho, sobretudo as mulheres: as mães de família ou as solteiras. Nesta situação, os ganhos casuais das mulheres eram essenciais para complementar o ordenado masculino e garantir o mínimo à subsistência precária da classe pobre. A maioria das famílias não tinha renda fixa visível e os rendimentos instáveis e insuficientes dos homens criavam a necessidade dos ganhos suplementares das mulheres que, no maior número de casos, não podiam se dedicar apenas às tarefas do lar e de subsistência. O resultado desta interdependência entre os ganhos de maridos e suas companheiras para a sobrevivência da família, muitas vezes podia significar um reforço dos elos de união do casal e um aumento da solidariedade, dos gestos de auxílio mútuo entre os integrantes do grupo de parentesco.

Quando não estava relativamente estabilizada nas funções domésticas, que era o setor que mais lhe oferecia oportunidades de emprego, a trabalhadora saía à cata das tarefas ocasionais, ligadas à prestação de serviços para as famílias burguesas. Geralmente as casadas e com filhos ainda pequenos, dada à dificuldade em assumir compromissos regulares e manter um ritmo constante de trabalho quando trabalhavam fora de casa, preferiam trabalhar por dia. O trabalho esporádico, casual, ajustava-se mais a sua realidade de mães de família com numerosa prole pequena e aos problemas decorrentes da sua função de progenitoras, como nos casos de doenças das crianças, que as impossibilitavam, temporariamente, de se afastar de casa; crianças ainda pequenas, que não contribuíam financeiramente para o orçamento doméstico e só aumentavam as despesas. Para fugir ao estado de miséria crônica é que estas enérgicas mulheres saíam à procura de trabalho (PINTO, 1994, p.171-173) .

Normalmente, esses trabalhos nos quais se entregavam as mulheres eram na verdade extensões de suas atribuições no lar, como por exemplo professora, enfermeira, datilógrafa, telefonista, operária das indústrias têxteis, de confecção e alimentícia. Já em 1919, no Distrito Federal, as mulheres alcançam o percentual de $55,1 \%$ contra $54,9 \%$ de homens no que se refere ao desenvolvimento de tarefas e ocupação de cargos no ramo das indústrias de vestuário e toucador. Em São Paulo, nesse mesmo ano, no ramo das indústrias têxteis, a diferença percentual entre mulheres e homens na ocupação total dos cargos cresce para $10,4 \%$, contabilizando $55,2 \%$ de mulheres contra $44,8 \%$ de homens. Os salários das mulheres eram sempre inferiores aos dos homens, mesmo contando as variações percentuais para mais ou para menos entre os diferentes ramos da atividade industrial, como nos mostra o censo de 1919 referente aos salários de homens e mulheres adultos: na indústria têxtil o salário médio em mil réis por dia era de 5.329 para os homens e 3.738 para as mulheres; já no ramo alimentício a diferença era de 5.111 para homens e 2.957 para as mulheres e na indústria do vestuário a contabilidade era de 6.712 para os homens contra 3.652 para as mulheres (FAUSTO, 1976, p.XI-XVI).

Nas décadas de 20 e 30, a divisão sexual do trabalho e a consciência das mulheres sobre elas mesmas estavam mudando significativamente e em lugar algum essas mudanças eram mais visíveis que nos grandes centros urbanos: ali, as famílias eram menores, o dia de trabalho mais curto, havia os salários para quem não estava desempregado, o desenvolvimento industrial e urbano, o acesso a uma melhor escolaridade, a divulgação pela imprensa de uma participação maior das mulheres no espaço público sobretudo depois da Primeira Guerra, o avanço do feminismo e as freqüentes reivindicações das mulheres por maiores oportunidades acabaram por abrir novas profissões para as brasileiras fora do lar.

Particularmente com relação aos filmes, o consumismo, fruto desse processo de industrialização e de massificação, pode ser visto do ponto de vista de um capitalismo que tenta cooptar as novas demandas do 
feminismo e as necessidades de expandir a força de trabalho feminina, com a criação de um novo "mercado feminino", além dos desejos das mulheres pela sexualidade, poder, liberdade e prazer que poderiam ser canalizado para uma "compra passiva" e para comodidades consumidas pela massa.

Influenciadas pelos novos papéis femininos representados no cinema, as mulheres tinham esperança de viver "vidas diferentes" das de suas mães. As principais ruas de comércio na cidade começaram seu reinado como o centro da moda para a jovem trabalhadora - o local adequado para sua nova e tão ostentada condição. As costureiras de roupas finas continuavam apresentando os caros cetins e brocados; e as vitrines ainda exibiam nos manequins suas roupas perfeitamente drapeadas. Mas a alta moda não conseguia deter a imaginação das jovens. As imagens imitativas de Jean Harlow, Greta Garbo e Jean Crawford desfilavam pelas principais ruas quando elas brilhavam nas telas de cinema. Porém poucas podiam comprar as novas roupas em lojas.

As mães, irmãs e amigas apressadamente copiavam o vestuário das estrelas utilizando materiais baratos adquiridos em feiras ou lojas de departamentos igualmente baratas. Essas relações de produção/reprodução cultural que se dão no cotidiano nos deixa entrever a relação entre consumo e produção cultural, baseando-se no fato de que "o consumo cultural de massas caracteriza as sociedades ocidentais a uma produção racionalizada, expansionista, tanto quanto centralizada, estrondosa e espetacular, corresponde uma outra produção qualificada de 'consumo "'. Dessa forma o consumo cultural é tomado, ele próprio, como uma produção, que evidentemente não fabrica nenhum objeto, mas constitui representações que nunca são idênticas às que o produtor, o autor ou artista, incutiram na sua obra. Esta produção é ardilosa, encontra-se dispersa, mas insinua-se por toda a parte, silenciosa e quase invisível, uma vez que não assinala a sua presença com produtos próprios mas com 'maneiras de utilizar' os produtos impostos por uma ordem economicamente dominante (PINTO, 1991).

Nesse sentido é emblemático um dos contos de António de Alcântara Machado, que mostra esse processo de absorção e reinvenção dos signos culturais hollywoodianos:

A rua Barão de Itapetininga é um depósito sarapintado de automóveis gritadores. As casas de modas (AO CHIC PARISIENSE, SÃO PAULO -PARIS, PARIS ELEGANTE) despejam nas calçadas as costureirinhas que riem, falam alto, balançam os quadris como gangorras...(...) o vestido de Carmela coladinho no corpo é de organdi verde. Braços nús, colo nú, joelhos de fora. Sapatinhos verdes. Bago de uva Marengo maduro para os lábios dos amadores reflete a boca reluzente de carmim primeiro, depois o nariz chumbeva, depois os fiapos de sombrancelha, por último as bolas de metal branco na ponta das orelhas descobertas...(...) Deante de Álvares de Azevedo (ou Fagundes Varela) o Angelo Cuoco de sapatos vermelhos de ponta afilada, meias brancas, gravatinha deste tamanhinho, chapéu à Rodolfo Valentino, paletó de um botão só, espera há muito com os olhos escangalhados de inspeccionar a rua barão de Itapetininga (MACHADO, 1982, p.33-38).

A influência do cinema hollywoodiano no Brasil, decisiva para a construção de cultura uma cosmopolita de fachada, enveredou-se por vários caminhos: substituiu a coroa dos reis pela auréola efêmera das estrelas da terra, construindo um mundo idealizado e romântico, onde a moda e os costumes passaram a ser apreendidos não mais na tradição familiar ou no contato com os meios tradicionais de educação (escola, igreja, catecismo etc), mas antes através de uma grande tela, que figurava um mundo novo a ser imitado e reinventado

É de temer-se, no entanto, que seguido sempre o mesmo rumo cheguemos à mesma situação de hipertrofia imaginativa para uns e obturidade para outros. Tal é a obsessão cinematográfica. Não falta por cá quem viva para o cinema, banalizado e materializado assim como o arroz doce e a marmelada. Não escasseiam também os que, não contentes com isso, vivem para além das telas e das fitas... Cúmulo da abstração, armando-se em lindas cabecinhas cinematógrafos ideais em que se projetam - projeções de projeções - reminiscências de filmes e vidas inteiras de atores e atri- 
zes, medíocres e nulos na generalidade. E nesses cinemas de cinemas, onde há sempre a meia-luz e a lâmpada misteriosa de uma idéia central, rompem dramas e paixões rebentam, como no outro cinema.

Há quem prosseguindo nesse ardor, traga ao peito medalhões com heróicas efígies norte-americanas... E - ó maior de santa bisavozinhas que se foram morrendo no seu quarto, ao pé do sagrado nicho da Senhora das Dores! - Existem mais quem traga à cabeceira, em lugar do antigo Santo Antonio, o descabelado retrato de George Walsh (O Estado de São Paulo, 5/5/1920).

Avulta nas crônicas cinematográficas da época temáticas do universo feminino, pois que é indiscutível que o universo cultural hollywoodiano, já nessa época, representava fonte inexaurível de padrões de hábitos, costumes, comportamentos, valores, moda; enfim, de um "modus vivendi" feminino.

É emblemático dessa influência o episódio escrito por Blaise Cendrars em um de seus contos, entitulado "As negras Louras" em que ele conta que estava no Brasil na época em que saiu a "A Vênus Platinada”, filme

"que fez tal sucesso no Rio de Janeiro que em menos de uma semana todas as belas mulatas e as negras indolentes que saem para passear no fim da tarde na Avenida ou para desfrutar do ar fresco à beira-mar na praia do Flamengo, haviam mandado descolorir os cabelos e se maquiavam todas de cor-de-rosa.(...) Era tão engraçado! Mas era ao mesmo tempo inquietante, pois todas elas pareciam não ser mais que o avesso delas mesmas como esses personagens que entrevemos por transparência quando examinamos um negativo a olho nu. Imagine só aquele cortejo de negras louras à luz do crepúsculo, à contraluz, com a nódoa clara de seu rosto maquiado e seus cabelos mortos, mas brilhantes! Um cortejo de fantasmas, poder-se-ia dizer. Um dia cheguei a encontrar uma negra que tinha tingido os cabelos com hena e exibia o mais belo ruivo irlandês. Era uma criatura soberba, mas ruiva, soberbamente ridícula (CENDRARS, 1990, p.126-129).

O discurso sobre consumismo esteve em alta no final dos anos 20. Stewart Ewen (EWEN, 1976) argumenta que a indústria da propaganda dos anos 10 e 20 desenvolveu uma nova estratégia para esta nova fase do capitalismo baseado no excedente dos bens produzidos em massa. A medida que a produção em massa se tornou manufaturada, muitos dos bens que uma vez eram produzidos por mulheres em suas casas (individual ou coletivamente), passaram a ser produzidos em larga escala nas fábricas. As mulheres eram vistas como o alvo ideal dessa produção escalar, além de se veicular a idéia de que estas atividades eram finalmente gratificantes para suas vidas.

$\mathrm{O}$ autor descreve dois esquemas de ataque dirigidos ao público feminino, via cinema e publicidade. Uma das estratégias era de continuar a dizer que as mulheres eram donas de casa e mães - no lugar de sua profissão-, mesmo sabendo que a grande maioria delas estavam trabalhando fora desde a $1^{\text {a }}$. Guerra Mundial. As propagandas tentavam fazer com que as mulheres se identificassem com seus lares, mas redefiniam o "lar" para que o consumo capitalista não se perdesse, criando um novo papel para as mulheres, o de "administradoras do lar... dirigindo-o ..., deixando com que ela selecionasse e consumisse todos os bens e serviços que a sociedade estava produzindo" (CENDRARS, 1990, p.168).

Além disso, a publicidade e o cinema, jogando com a fantasia e a excitação, permitiram que as mulheres imaginassem um fim para o enfadonho trabalho doméstico e para o desejo crônico de outra vida através de imagens de cozinhas e eletrodomésticos modernos, de roupas e maquiagens bonitas e baratas em cartaz nas telas de cinema e nas novas revistas femininas, acrescentando assim nova dimensão ao romantismo. Poucas mulheres compravam fogão à gás ou substituíam os lavatórios externos pelos banheiros hiper-higiênicos, revestidos de pastilhas e passadeiras. Apesar da aparente facilidade traduzida por uma "gama variada de aparelhos elétricos oferecidos ao público e por anúncios, nos quais as mulheres executavam os mais difíceis e sujos serviços domésticos sempre sorrindo", ainda era muito restrito o acesso a novos utensílios e a serviços como eletricidade e água encanada.(MALUF E MOTT, 1998, 
p.403). Assim, o que se verifica é uma desigual aquisição dos novos bens de consumo oferecidos pela indústria de massas, pois somente uma parcela da população composta por aqueles que "podiam pagar" é que desfrutavam de suas benesses.

As idéias de liberdade e igualdade para as mulheres foram rapidamente disseminadas pelas feministas da época de 1900-1929 e foram conscientemente incorporadas na retórica da propaganda, como uma arma adicional de seu arsenal.

Pesquisas feitas com as propagandas de jornais comerciais mostram que, por exemplo, os publicitários e os diretores de cinema estavam cientes de que fumar cigarros era um símbolo da emancipação feminina e usavam esta associação em suas propagandas e filmes. Cigarros eram oferecidos como símbolo de liberdade - e assim construiu-se um novo mercado para as indústrias tabagistas.

Escolha e liberdade para as mulheres, tornaramse sinônimos da produção em massa de bens de consumo, despojando-os de suas conotações e alterando a estrutura da sociedade. Entretanto, os efeitos da idéia de que a liberdade e a escolha eram legitimamente desejados pelas mulheres, não eram inteiramente aceitos pela Big Business. Este aspecto contraditório do consumismo capitalista, em suas incessantes pesquisas por matérias-primas e novos mercados, incentiva ideologias potencialmente subversivas e que tem relação com cada discurso relativo ao women film.

A outra estratégia de propaganda dirigida para as mulheres com gosto similar por seus objetivos e temas, concentra-se mais em um tipo diferente de "feminilidade", mulheres fisicamente parecidas e usando a retórica e a técnica dos então emergentes "campos do ego e da filosofia social."

Enquanto a ideologia da beleza, não era novidade, a propaganda do século XX introduzia a idéia de que a beleza não era um bem dado, era ao contrário um bem que poderia ser conquistado por qualquer mulher, desde que ela usasse os produtos "corretos": cosméticos, tons e marcas de maquiagem, moda e tratamentos de beleza. A propaganda reiterava continuamente às mulheres que suas habilidades para manter um marido deriva da aceitação de seu look, depende de sua aparência. Valendo-se do conceito de "ser social" desenvolvido pela psicologia social: a idéia de que a identidade era baseada na reação dos outros, representava-se mulheres rodeadas por olhos críticos, vigilantes, que buscavam defeitos que poderiam causar-lhes um ostracismo social.

“Não há estrela sem 'sex-appeal' e não há 'sex-appeal' sem maquiagens. Mas sem a linha dos cabelos não há beleza possível..." Eis o primeiro aforismo de Wally Westmore, o criador da estética do rosto do cinema.

Estabelecido há vinte anos em Hollywood, onde se especializou nos tratamentos de beleza e onde se tornou famoso por suas pesquisas e seus êxitos repetidos e muito comentados, Wally Westmore, mestre maquiador da Paramount, é ao mesmo tempo o inventor e o fabricante da maioria das estrelas de renome mundial. De modo que seu julgamento, tal como o do papa em matéria de religião, passa por ser infalível quando se trata de beleza levada à tela.

Especialista em 'sex-appeal', é ele que submete as artistas mais cotadas, portanto as mais altivas e intangíveis, à humilhação de um teste fisiológico trimestral e que entrega a cada uma delas a ficha pessoal de beleza, à qual todas estão sujeitas. Do mesmo modo, não há principiante, não há 'starlet' com possibilidade de vencer no cinema se Westmore, esse mágico clarividente, não fixar seu 'gênero' e depois seu 'tipo'

"Diz-se comumente que os olhos são as janelas da alma; isto é bem possível afinal, mas o estilo atual do penteado de Milady é a chave de seu 'sex-appeal"', afirma Westmore. "Os olhos, a boca, a compleição, a fisionomia podem ser impecáveis e bem proporcionais, mas não há verdadeiro "sex-appeal" para uma mulher sem o edifício, sem o artifício do penteado, pois todos os seus encantos naturais só terão equilíbrio graças à linha de seus cabelos”(...) “A maioria das estrelas tem defeitos que podemos remediar através da maquiagem, da iluminação, ou ainda de trucagens fotográficas; mas se a massa e a implantação de seus cabelos forem assimétricas, ou mesmo se a linha de seu penteado estiver fora de tom, todos os nossos esforços serão em vão e seu rosto parecerá sempre desproporcional em suas diferentes partes, isto é, parecerá contrafeito e atormentado, portanto sem beleza" (CENDRARS, 1990, p.124). 
Apenas com o uso dos produtos designados poderia se prevenir um desastre: as mulheres eram educadas para se auto-conceberem como coisas, a serem criadas para competirem umas contra as outras, pintadas e esculpidas pelas propagandas do mercado moderno; as técnicas de tentativa de sobrevivência neste mundo da modernidade construída tornaram a sua mais conspícua forma de se auto definirem.

O modo como esta ideologia foi tomada pelo cinema hollywoodiano e a atual conexão entre os filmes e as indústrias de propaganda é discutida por Charles Eckert (ECKERT, 1976). O cinema hollywoodiano, especialmente das décadas de 20-30, era estruturado em parte sobre a apresentação da mulher como um objeto glamouroso, disputado e consumido, e parte sobre a criação de um mise en scène cujos fetiches são objetos consumidos e um estilo de vida consumista. Eckert articula esses modos de representação com a prática da propaganda dos produtos que estavam conectados com a produção industrial e o cinema hollywoodiano. Significativamente, as principais indústrias de bens de consumo que recorriam amplamente a estratégia da exposição de seus produtos em filmes e de usar estrelas como propagandas, estavam almejando principalmente como alvos o consumo feminino: modas, cosméticos, móveis e utensílios para casa.

Não escapava aos empresários modernos o fato de que as mulheres, após a Primeira Guerra Mundial, sejam elas operárias, das classes médias e da elite, cada vez mais estavam presentes no espaço público das ruas, gerenciando diretamente ou através de seus serviçais a aquisição de bens de consumo

O discurso consumista, bem como sua mensagem de que a felicidade das mulheres depende de suas criações próprias, da aquisição de objetos desejados, através do consumo dos produtos de massa era, no final dos anos 30, proveniente em grande parte, do fluxo de idéias e imagens contemporâneas.
Com o desenvolvimento urbano, o objetivo de higienização das cidades e a preocupação em modernizar o espaço público, serviços antigos como por exemplo o da lavagem de roupa "para fora" foram condenados juntamente com os velhos hábitos da velha cidade, arcaica e fétida, dando lugar às "maravilhas elétricas", a substituição do velho fogão a carvão e da espiriteira pelo fogão a gás, interpretado como sinal de bom gosto e prestígio da família que o possuísse; ou ainda a edificação da própria cozinha, higienizada, composta pelas maravilhas elétricas, revestida de pisos claros e profiláticos, equipada com um exército de aparadores e guardanapos bordados, além das panelas em alumínio brilhante, iluminação incandescente e pedras de mármore ou granito enfeitando as soleiras de entrada nesse mundo mágico e moderno que é a cozinha.

Porém, o que se sabe de fato é que muitas cozinhas permaneceram até meados deste século como um apêndice da casa, um puxado coberto por telhasvãs, voltado mais para o quintal do que propriamente para o interior de residência. "Era um lugar quente, enfumaçado, cheio de picumã, engordurado pela carne-seca, lingüiça e toucinho pendurados no fumeiro, com os tijolos do chão desgastados pelas pancadas do machado na lenha, onde a dona de casa permanecia de cócoras, debruçada sobre gamelas e peneiras, ou em pé, socando o pilão, o que deixava as mais novas e inexperientes com as mãos vermelhas e cheias de bolhas em razão do esforço repetido" (...)"para a limpeza das panelas e frigideiras de ferro, pedra, barro, cobre e, moderadamente, alumínio, consideradas mais econômicas e higiênicas, utilizava-se sabão feito em casa com uma mistura de cinzas e folha de pau de pita; as panelas eram areadas com areia, cacos de telha reduzidos a pó e batatinha" (MALUF e MOTT, 1998, p.412-413).

Nesse alvoroço de mudanças que exigia inovações e criatividade, esgueiram-se em contraposição tendências ameaçadoras de mobilização para a ação co- 
letiva e uniformizadora, que viriam a gerar o planejamento e a massificação. $\mathrm{O}$ espaço aberto para o provisório e as inovações em São Paulo tornava-se perigosamente propício a forjar identidades através da exploração do ideal de uma raça nova de homens disciplinados e modernos.(DIAS, 1992, p.XIII) Pensemos na urbanização acelerada e na remodelação da cidade. Elas criaram espaços de desfile e exibição social, mais ou menos ostensivos, conforme a área e conforme o público, implicados no consumo, o qual

\section{Bibliografia}

CENDRARS, Blaise. Hollywood 1936. São Paulo: Brasiliense, 1990.

DIAS, Maria Odila Leite da Silva. Quotidiano e Sobrevivência em São Paulo no século XIX. São Paulo: Brasiliense, 1984 "Hermenêutica da Narrativa". In: SEVCENKO, Nicolau. Orfeu Extático na Metrópole. São Paulo, sociedade e cultura nos frementes anos 20. São Paulo: Cia das Letras, 1992.

ECKERT, Charles. "The Carole Lombard in Macycs Window". In: Quarterly Review of Film Studies. Winter, 1976.

EWEN, Stuart. Captains of Consciousness. New York: McGraw Hill, 1976.

FAUSTO, Boris. Trabalho Urbano e Conflito Social, 1890-1920. São Paulo-Rio de Janeiro: Difel, 1976.

GALVÃO, Maria Rita Eliezer. Crônica do Cinema Paulistano. São Paulo: Ática, 1975.

LOTITO, Marcia Padilha. A Cidade como Espetáculo. Publicidade e Vida Urbana na São Paulo dos anos 20. São Paulo, 1997. (Dissertação de Mestrado), USP-FFLCH.

MACHADO, Antônio de Alcântara. Brás, Bexiga e Barra Funda. São Paulo: Imprensa Oficial do Estado-IMESP/DAESP, 1982.

MALUF, Marina e MOTT, Maria Lúcia. "Recônditos do mundo pela publicidade preenchia o repertório das fantasias associadas ao sucesso nos negócios e no amor. No caso do cinema, que exerceu papel fundamental nesse sentido, pode-se verificar a propaganda ostensiva de vários valores que compunham esse ideário moralizador, moderno e civilizado, através dos filmes hollywoodianos, que compunham na tela a materialização, através da imagem, do um sonho americano tornado por nós como o sonho de modernização e cosmopolitismo por excelência.

feminino". In: SEVCENKO, Nicolau (Org.). História da Vida Privada no Brasil. São Paulo: Cia das Letras, v.3, 1988. PINTO, Maria Inez Machado Borges. Cotidiano e Sobrevivência. A vida do trabalhador pobre na cidade de São Paulo, 1890-1914. São Paulo: Edusp, 1994.

. "A cena muda: maquinismo e lazer na metrópole cafeeira, 1910-1930”. In: Fontes Alternativas para a História (Anais do X Simpósio de História). Edição Especial da Revista de História ${ }^{\circ} 5$. Vitória: Centro de Estudos Gerais/Depto de História da Universidade Federal do Espírito Santo, 1997. "Historiografia Contemporânea da Cultura Popular: Tendências e Impasses". In: História em Debate: Problemas, Temas e Perspectivas. Anais da XVI ANPUH.RJ: CNPq e Infour, 1991.

SEVCENKO, Nicolau. Orfeu Extático na Metrópole. São Paulo, sociedade e cultura nos frementes anos 20. São Paulo: Cia das Letras, 1992.

"A Capital irradiante: técnica, ritmos e ritos do Rio". In: SEVCENKO, Nicolau (Org.). História da Vida Privada no Brasil. São Paulo: Cia das Letras, v.3. 1988.

Endereço da Autora: Depto. de História - FFLCH/USP - Av. Prof. Lineu Prestes, 338 - CEP 05508-900 - Cidade Universitária - SP Brasil - Tel. (0xx) 11- 3818-3701 - Fax (0xx) 11- 210-2314 